\title{
Forced vibrations of joined fibrous concrete beams at their approximation by system with two DOF
}

\author{
N. Surianinov, S. Neutov, M. Sydorchuk \\ Odesa State Academy of Civil Engineering and Architecture Didrikhsona str. 4, 65029 Odesa, Ukraine \\ Corresponding author. E-mail: sng@ogasa.org.ua
}

Paper received 16.07.18; Accepted for publication 23.07.18.

https://doi.org/10.31174/SEND-NT2018-179VI21-18

\begin{abstract}
There are considered forced vibrations of the systems of two fibrous concrete beams of rectangular cross-section. Beams are joined to each other and to fixed support by four reinforcing rods, simulating connection of girth rails of foundation beams. With the aim of result verification that were achieved in experimental way there was given the analytical solution of the problem using the method of decomposition by eigenmodes of vibrations. Herewith the system under consideration is approximating as a system with two degrees of freedom. It is noted that calculations 6 based on proposed approach, had shown good coincidence with experimental data.
\end{abstract}

Keywords: forced vibrations, frequency, differential equation, fibrous concrete, fiber, eigenmode.

Introduction. In the Odessa state academy of civil engineering and architecture there are performed complex tests of different types of fibrous concrete structures [1-3] at different types of tests (static, dynamic, eigenvalue buckling) at change of fibrous mixtures parameters. There are experimentally determined the optimum parameters of these mixtures, according to construction functional purpose. During performed tests there were determined the cubic strength of steel fiber concrete on the samples of $100 \times 100 \times 100 \mathrm{~mm}$ and prism strength on the samples of 100x100x400 mm [4]. Herewith the percent of discrete reinforcement varied values $0.5 \%, 1.0 \%$ and $1.5 \%$. The coarse aggregate size was $\leq 10 \mathrm{~mm}$ in the first test series and $\leq 20 \mathrm{~mm}$ in the second test series. Processing of tests results had shown that the optimum parameters of steel-fiber concrete mixture is the matrix with coarse aggregate $\leq 10 \mathrm{~mm}$ at $1.0 \%$ of fibrous reinforcement.

There was used steel fiber of LLC "Stalkanat-Silur" production (Fig. 1) that is manufactured according to European standard [5].

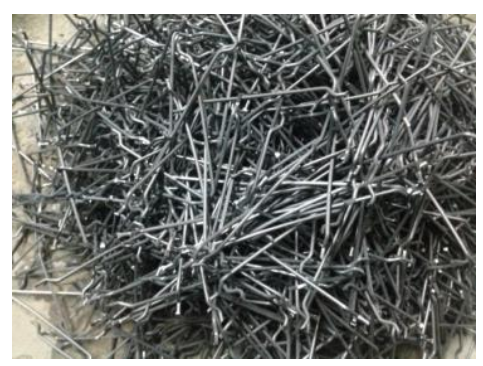

Figure 1 Fiber with bent ends

The aim of this work is to study the forced vibrations of steel fibrous concrete beams.

Research results. On the base of determined by us optimum composition of fibrous concrete mixture there were made several types of constructions: beams, arches, plates, cylindrical panels and shells with different variants of reinforcement - only fiber or combined, using fiber and rod reinforcement.

All of these constructions was subjected to multifaceted tests - static, dynamic and eigenvalue buckling.

One of the experimentally researched problems are forced vibrations of beams of rectangular cross-section. During experiments, two identical beams was joined by four reinforcing rods, simulating connection of girth beams or foundation beams (Fig. 2) and then they were subjected to forced vibrations. In this case there were tested beams with $100 \%$ fiber reinforcement on the whole volume, with fibrous reinforcement of tensed zone to the middle of the cross-section height and with combined reinforcement with fiber and rod reinforcement.

Here we will consider the analytical approach to solution of indicated problem.

Let the external constraining forces (Figure 2) are changing by arbitrary periodic (but nonharmonic) law.

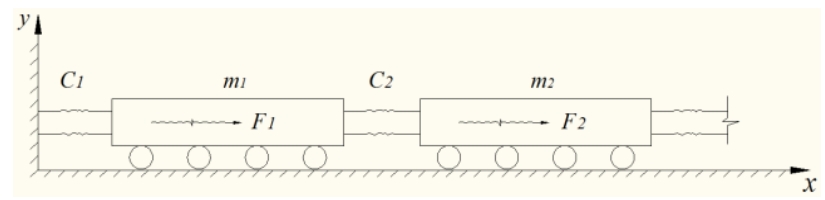

Figure 2 External forces scheme

Here $F_{1}, F_{2} \ldots$ are the constraining forces; $C_{1}, C_{2} \ldots$ are the summary stiffnesses of connection reinforcement rods.

As it is known, the periodic external constraining forces can be represented as a sum of harmonics. After that on the base of superposition principle we can determine summary movement as a sum of movements caused by every of harmonics separately. As a result the problem under consideration is reducing to the problem of forced vibrations of the system of fibrous concrete beams under the action of harmonic constraining force $F=F_{i} \sin p t$ (or, that is the same, $F=F_{i} \cos p t$ ).

Let's consider the solution of this problem by known in dynamics method of decomposition by eigenmodes of vibration [6-8].

Movement equations of every of beams (for simplifying of the solution we will consider only two beams; after that we will generalize results) has the same form that is for free vibrations but with the presence of right part:

$$
\left\{\begin{array}{l}
m_{1} \ddot{x}_{1}+C_{1} x_{1}-C_{2}\left(x_{2}-x_{1}\right)=F_{1} \sin p t ; \\
m_{2} \ddot{x}_{2}+C_{2}\left(x_{2}-x_{1}\right)=F_{2} \sin p t .
\end{array}\right.
$$

Solution of system (1) represents the sum of general solution of corresponding homogenous system and some partial solution of system (1) [9-11]:

$$
\left\{\begin{array}{l}
x_{1}=a_{11} \sin \left(\omega t+\alpha_{1}\right)+a_{12} \sin \left(\omega t+\alpha_{2}\right) \\
x_{2}=a_{21} \sin \left(\omega t+\alpha_{1}\right)+a_{22} \sin \left(\omega t+\alpha_{2}\right)
\end{array}\right.
$$


where $\omega$ - eigenfrequency; $a_{i j}$-amplitude, at that $i$ - mass number, $j$ - frequency number.

Addendum part of solution (2), which describes vibrations with eigenfrequency, rapidly decays. The base of solution is its second part, corresponding to continuous stationary process of forced vibrations.

Generally speaking, two kinds of solutions satisfy the homogeneous equations that correspond to equations (1):

$$
\begin{aligned}
& \left\{\begin{array}{l}
x_{1}=a_{11} \sin \left(\omega_{1} t+\alpha_{1}\right) ; \\
x_{2}=a_{21} \sin \left(\omega_{1} t+\alpha_{1}\right)
\end{array}\right. \\
& \text { and } \\
& \left\{\begin{array}{l}
x_{1}=a_{12} \sin \left(\omega_{2} t+\alpha_{2}\right) ; \\
x_{2}=a_{22} \sin \left(\omega_{2} t+\alpha_{2}\right) .
\end{array}\right.
\end{aligned}
$$

Let's substitute in turn (3) and (4) into homogenous equations, corresponding to (1). First of all, we calculate the second derivatives of generalized coordinates.

$$
\left\{\begin{array}{l}
\ddot{x}_{1}=-\omega_{1}^{2} a_{11} \sin \left(\omega_{1} t+\alpha_{1}\right) ; \\
\ddot{x}_{2}=-\omega_{1}^{2} a_{21} \sin \left(\omega_{1} t+\alpha_{1}\right) .
\end{array}\right.
$$

and, analogically,

$$
\left\{\begin{array}{l}
\ddot{x}_{1}=-\omega_{2}^{2} a_{12} \sin \left(\omega_{2} t+\alpha_{2}\right) ; \\
\ddot{x}_{2}=-\omega_{2}^{2} a_{22} \sin \left(\omega_{2} t+\alpha_{2}\right) .
\end{array}\right.
$$

Substitution gets two groups of relations that will be needed later:

$$
\begin{aligned}
& \left\{\begin{array}{l}
-m_{1} \omega_{1}^{2} a_{11}+C_{1} a_{11}-C_{2}\left(a_{21}-a_{11}\right)=0 ; \\
-m_{2} \omega_{1}^{2} a_{21}+C_{2}\left(a_{21}-a_{11}\right)=0 ;
\end{array}\right. \\
& \left\{\begin{array}{l}
-m_{1} \omega_{2}^{2} a_{12}+C_{1} a_{12}-C_{2}\left(a_{22}-a_{12}\right)=0 ; \\
-m_{2} \omega_{2}^{2} a_{22}+C_{2}\left(a_{22}-a_{12}\right)=0 ;
\end{array}\right.
\end{aligned}
$$

Now let's replace unknown generalized coordinates $x_{1}$ and $x_{2}$ by two new functions $f_{1}(t)$ and $f_{2}(t)$ according to equality:

$$
\left\{\begin{array}{l}
x_{1}=a_{11} f+a_{12} f_{2} \\
x_{2}=a_{21} f_{1}+a_{22} f_{2}
\end{array} .\right.
$$

where $a_{11}$ and $a_{12}-$ arbitrary numbers, related to $a_{21}$ and $a_{22}$ by relations, that are known from eigenmodes of vibrations.

Substituting (7) into (1), we will get the system of equations of new functions $f_{1}(t)$ and $f_{2}(t)$ :

$$
\begin{aligned}
& \left\{\begin{array}{l}
m_{1}\left(a_{11} \ddot{f}_{1}+a_{12} \ddot{f}_{2}\right)+C_{1}\left(a_{11} f_{1}+a_{12} f_{2}\right)-C_{2}\left(a_{21} f_{1}-a_{11} f_{1}+a_{22} f_{2}-a_{12} f_{2}\right)=F_{1} \sin p t ; \\
m_{2}\left(a_{21} \ddot{f}_{1}+a_{22} \ddot{f}_{2}\right)+C_{2}\left(a_{21} f_{1}-a_{11} f+a_{22} f_{2}-a_{12} f_{2}\right)=F_{2} \sin p t .
\end{array}\right. \\
& \left\{\begin{array}{l}
m_{1}\left(a_{11} \ddot{f}_{1}+a_{12} \ddot{f}_{2}\right)+f_{1}\left[C_{1} a_{11}-C_{2}\left(a_{21}-a_{11}\right)\right]+f_{2}\left[C_{1} a_{12}-C_{2}\left(a_{22}-a_{12}\right)\right]=F_{1} \sin p t ; \\
m_{2}\left(a_{21} \ddot{f}_{1}+a_{22} \ddot{f}_{2}\right)+f_{1} C_{2}\left(a_{21}-a_{11}\right)+f_{2} C_{2}\left(a_{22}-a_{12}\right)=F_{2} \sin p t .
\end{array}\right.
\end{aligned}
$$

Use of relations (5) and (6) leads to quite obvious simplifications of equation (9):

$$
\begin{aligned}
& \left\{\begin{array}{l}
m_{1}\left(a_{11} \ddot{f}_{1}+a_{12} \ddot{f}_{2}\right)+m_{1} f_{1} \omega_{1}^{2} a_{11}+m_{1} f_{2} \omega_{2}^{2} a_{12}=F_{1} \sin p t ; \\
m_{2}\left(a_{21} \ddot{f}_{1}+a_{22} \ddot{f}_{2}\right)+m_{2} f_{1} \omega_{1}^{2} a_{21}+m_{2} f_{2} \omega_{2}^{2} a_{22}=F_{2} \sin p t .
\end{array}\right. \\
& \quad\left(m_{1} a_{11}^{2}+m_{2} a_{21}^{2}\right) \ddot{f}_{1}+\left(m_{1} a_{11} a_{12}+m_{2} a_{21} a_{22}\right) \ddot{f}_{2}+ \\
& +\omega_{1}^{2}\left(m_{1} a_{11}^{2}+m_{2} a_{21}^{2}\right) f_{1}+\omega_{2}^{2}\left(m_{1} a_{11} a_{12}+m_{2} a_{21} a_{22}\right) f_{2}=\left(F_{1} a_{11}+F_{2} a_{21}\right) \sin p t .
\end{aligned}
$$

Coefficients at function $f_{2}$ and its second derivative represents the orthogonality condition of eigenmodes of vibrations and, consequently, are equal to zero.

This in its turn means that from (11) we will get function $f_{2}$ and its second derivative. We get differential equation for function $f_{1}$ :

$$
\ddot{f}_{1}+\omega_{1}^{2} f_{1}=\frac{F_{1} a_{11}+F_{2} a_{21}}{m_{1} a_{11}^{2}+m_{2} a_{21}^{2}} \sin p t
$$

In analogical way we comes to differential equation for function $f_{2}$ :

$$
\ddot{f}_{2}+\omega_{2}^{2} f_{2}=\frac{F_{1} a_{12}+F_{2} a_{22}}{m_{1} a_{12}^{2}+m_{2} a_{22}^{2}} \sin p t .
$$

Conclusion. Thus, this method leads to separate differential equations (12) and (13), each of which describes vibrations of a system with one degree of freedom.

If fractions in right part (12) and (13) denote through $P_{1}$ and $P_{2}$ respectively, the stationary part of solution will took a form:
We multiply first of equations (10) by $a_{11}$, second by

$$
\begin{aligned}
& f_{1}=\frac{P_{1}}{\omega_{1}^{2}-p^{2}} \sin p t \\
& f_{2}=\frac{P_{2}}{\omega_{2}^{2}-p^{2}} \sin p t .
\end{aligned}
$$

After substitution (14) and (15) into (7), we will get generalized coordinates of forced vibrations of considered system of two fibrous concrete beams:

$$
\left\{\begin{array}{l}
x_{1}=\frac{a_{11} P_{1}}{\omega_{1}^{2}-p^{2}} \sin p t+\frac{a_{12} P_{2}}{\omega_{2}^{2}-p^{2}} \sin p t ; \\
x_{2}=\left(\frac{a_{21} P_{1}}{\omega_{1}^{2}-p^{2}}+\frac{a_{22} P_{2}}{\omega_{2}^{2}-p^{2}}\right) \sin p t .
\end{array}\right.
$$

It follows from the above arguments that such separate differential equations can be obtained at any number of beams, joining each other.

Calculations, performed on the base of considered method, had shown good match with experimental data. 


\section{ЛИТЕРАТУРА}

[1] Рабинович, Ф.Н.Композиты на основе дисперсноармированных бетонов. Вопросы теории и проектирования, технология, конструкции: монография / Ф. Н. Рабинович. - М.: Изд-во АСВ, 2004. -560 с.

[2] Талантова К.В. Сталефибробетон с заданными свойствами и строительные конструкции на его основе: дисс. ... д-ра. техн. наук / К.В. Талантова. - Барнаул, 2013. $-287 \mathrm{c}$.

[3] Клюев А.В., Нетребенко А.В., Дураченко А.В. Свойства бетонной матрицы при дисперсном армировании фибрами // Сборник научных трудов Sworld. -2014. - T. 16. - №2. - C. $96-99$.

[4] ДБН В.2.6-98:2009. Бетонні та залізобетонні конструкції. Основні положення. - К.: Мінрегіонбуд України, 2011. $73 \mathrm{c}$.

[5] BS EN 14889-1:2006 Fibres for concrete. Steel fibres. Definitions, specifications and conformity.
[6] Безухов Н.И. Устойчивость и динамика сооружений / Безухов Н.И., Лужин О.В., Колкунов Н.В. - М.: Высшая школа, 1987. -264 c.

[7] Бидерман В.Л. Теория механических колебаний / Бидерман В.Л. - М.: Высшая школа, 1980. - 408 с.

[8] Пановко Я.Г. Устойчивость и колебания упругих систем / Пановко Я.Г., Губанова И.И. - М.: Наука, 1987. - 352 с.

[9] Пискунов Н.С. Дифференциальное и интегральное исчисления. Т. 1 / Пискунов Н.С. - М.: Наука, 1985. - 430 c.

[10] Л.Я. Адрианова. Введение в теорию линейных систем дифференциальных уравнений. Уч. пособ. СанктПетербург: Изд-во Санкт-Петербургского университета, 1992 год. 239 с

[11] Арнольд. Обыкновенные дифференциальные уравнения. 4-ое изд. Ижевск: Удм.ГУ, 2000. -368 с
[1] Rabinovich F.: Kompozity na osnove dispersnoarmirovannykh betonov. Voprosy teorii i proyektirovaniya. tekhnologiya. Konstruktsii: monografiya, Moscow: ACB, 2004, 560 p. (in Russian)

[2] Talantova K.: Stalefibrobeton s zadannymi svoystvami i stroitelnyye konstruktsii na ego osnove. PhD thesis, Barnaul, 2013, 287 p. (in Russian)

[3] Klyuev A.; Netrebenko A.; Durachenko A.: Svoystva betonnoy matritsy pri dispersnom armirovanii fibrami, Collection of scientific papers Sworld, Ternopil, Vol.16, No. 2 (2014), pp. 96 - 99. (in Ukrainian)

[4] DBN V.2.6-98:2009: Betonni ta zalizobetonni konstruktsii. Osnovni polozhennia, Ministry for Regional Development, Building and Housing of Ukraine, Kyiv, 2011, 73 p. (in Ukrainian)

[5] BS EN 14889-1:2006 Fibres for concrete. Steel fibres. Defi-

\section{RFERENCES}

nitions, specifications and conformity.

[6] Bezukhov N.; Luzhin O.; Kolkunov N.: Ustoychivost i dinamika sooruzheniy, Moscow: Vysshaya shkola, 1987, 264 p. (in Russian)

[7] Biderman V.: Teoriya mekhanicheskikh kolebaniy, Moscow: Vysshaya shkola, 1980, 408 p. (in Russian)

[8] Panovko Y.; Gubanova I.: Ustoychivost i kolebaniya uprugikh sistem, Moscow: Science, 1987, 352 p. (in Russian)

[9] Piskunov N.: Differentsialnoye i integralnoye ischisleniya, Moscow V. 1: Science, 1985, 430 p. (in Ukrainian)

[10] Adrianova L.: Vvedeniye $\mathrm{v}$ teoriyu lineynykh sistem differentsialnykh uravneniy. Textbook of St. Petersburg University, St. Petersburg, 1992, 239 p. (in Russian)

[11] Arnold V.: Obyknovennyye differentsialnyye uravneniya, Izhevsk: 2000, 368 p. (in Russian)

\section{Forced vibrations of joined fibrous concrete beams at their approximation by system with two DOF}

N. Surianinov, S. Neutov, M. Sydorchuk

Abstract. There are considered forced vibrations of the systems of two fibrous concrete beams of rectangular cross-section. Beams are joined to each other and to fixed support by four reinforcing rods, simulating connection of girth rails of foundation beams. With the aim of result verification that were achieved in experimental way there was given the analytical solution of the problem using the method of decomposition by eigenmodes of vibrations. Herewith the system under consideration is approximating as a system with two degrees of freedom. It is noted that calculations 6 based on proposed approach, had shown good coincidence with experimental data.

Keywords: forced vibrations, frequency, differential equation, fibrous concrete, fiber, eigenmode. 